\title{
ICHNOLOGY AND SEDIMENTOLOGY REVEAL DEPOSITIONAL CHARACTERISTICS OF BAY-MARGIN PARASEQUENCES IN THE MIOCENE AMAZONIAN FORELAND BASIN
}

\author{
MURRAY K. GINGRAS ${ }^{1}$, MATTI E. RÄSÄNEN ${ }^{2}$, S. GEORGE PEMBERTON ${ }^{3}$, AND LIDIA P. ROMERO ${ }^{4}$ \\ ${ }^{1}$ Department of Geology, University of New Brunswick, P.O. Box 4400, Fredericton, New Brunswick, E3B 5A3, Canada \\ ${ }^{2}$ Department of Geology, University of Turku, Turku, FIN-20500, Finland \\ ${ }^{3}$ Department of Earth and Atmospheric Sciences, University of Alberta, Edmonton, T6G 2E3, Canada \\ ${ }^{4}$ Instituto Geológico Minero y Metallurgico, Av. Canada 1470, San Borja, Apartado 889, Lima 41, Peru \\ e-mail:mgingras@unb.ca
}

Abstract: Proposed depositional models for Miocene Amazon foreland basin strata (Pebas Formation, Peru) are controversial. Recent depositional models include lacustrine and tidally influenced, brackishwater embayment. This paper presents data that support tidally influenced, brackish-water deposition for at least part of Pebas time (1014 Ma). Two parasequences are presented (Santa Julia and Tamshiyacu). Both crop out along the Amazon River in Upper Amazonia near Iquitos, Peru. At these locations, abundant evidence of brackish-water, tidally influenced deposition is documented, including marginal marine bioturbation, sedimentary couplets, semidiurnal couplets (preserved in burrows), and pinstripe lamination. The deposits are locally highly bioturbated. At both locations ichnogenera normally associated with marine to brackish-water depositional environments are common. Three normally marginal-marine ichnofabrics are reported: (1) a Chondritesreburrowed, Planolites ichnofabric resident only in massive-appearing muds; (2) a Scolicia (Laminites), Thalassinoides, Ophiomorpha ichnofabric that is manifested as intensely bioturbated silty sands; and (3) a Thalassinoides-generated ichnofabric that is interpreted to have descended into consolidated substrates and is thus representative of the Glossifungites Ichnofacies. Several trace fossils contain laminated infills organized into distinct sedimentary couplets that are best interpreted as resulting from semidiurnal processes.

Six conclusions are arrived at: (1) sedimentological and ichnological data consistently indicate that sediment accumulation dominantly occurred in sporadically dysaerobic, marine to brackish water, under a tidal influence; (2) sediment accumulation occurred in bay-margin environments that prograded into a shallow, quiescent bay; (3) a stratified water column is indicated by the ichnofauna; (4) low accommodation space, repetitive and rapid adjustments of relative sea level, shallow wave base, and a stratified water column combined to generate an atypical parasequence architecture; (5) previously published isotopic data are consistent with sediment accumulation in brackish to marine water; and (6) marine incursion into Amazonia occurred during the Middle Miocene.

\section{INTRODUCTION}

The Pebas Formation (Middle Miocene 18-10 Ma; Solimöes Formation in Brazil) crops out along the Amazon River in eastern Peru (Fig. 1). Recently interpreted to represent lacustrine to oligohaline sedimentary conditions (Vonhof et al. 1998), it was suggested that a temporally insignificant, transient, and restricted inlet connected "Lake Pebas" to the Caribbean Sea; marine processes were generally not a factor controlling deposition. Isotopic (Vonhof et al. 1998) and paleontological data (Nuttall 1990; Lundberg et al. 1998; Vonhof et al. 1998) support these interpretations, whereas other paleontological (Rancy 1991; Hoorn 1993) and sedimentological evidence (Räsänen et al. 1995; Gingras et al. 2002) suggests that these deposits are tidally influenced. None of the aforementioned studies have considered the ichnological data present in the Pebas Formation. This is a notable oversight because trace fossils are invaluable paleoenvironmental indicators (Pemberton et al. 1982; Ekdale et al. 1984; Savrda and
Bottjer 1989; Bromley 1996), have genetic stratigraphic significance (Pemberton and MacEachern 1995; Savrda et al. 2001), and provide additional physical sedimentologic data, such as sedimentation rate and event deposition (Bromley 1996; Pemberton and MacEachern 1997; Gingras et al. 1999; Gingras et al. 2002).

It is demonstrated below that these deposits result from unique sedimentary responses to several parameters, including, limited accommodation space, high-order cyclicity, and restricted embayment waters. The sedimentary successions thereby provide an important addition to bay-margin facies models. The ichnological and sedimentological database lead to the final interpretations, which could not be arrived at without the integration of the two datasets. The ichnological/sedimentological interpretations show the difficulty of assessing benthic paleoecology in a multi-stress environment. Finally, an understanding of the paleogeography of the Amazon Ba$\sin$ is essential to understand its natural history. Several studies have noted the high biodiversity present in the Amazon Basin during the Miocene. These observations have been explained by climatic change (Van Der Hammen and Hooghiemstra 2000), island biogeography (Nores 1999), and variable habitat (Hooghiemstra and Van Der Hammen 1998).

\section{Study Locations}

This paper focuses on two exposures in cutbanks along the Amazon River in Upper Amazonia, near Iquitos, Peru. The sections include Santa Julia II (S 3 $20^{\prime} 17^{\prime \prime}$, W 71 $48^{\prime} 56^{\prime \prime}$ ) and Tamshiyacu (S $4^{\circ} 00^{\prime} 36^{\prime \prime}$, W $73^{\circ} 09^{\prime} 24^{\prime \prime}$ ) (Figs 1, 2). These locations illustrate different parts of the depositional system at approximately the same Middle Miocene time (Grassoretitriletes pollen zone; Räsänen et al. 1998).

\section{Geological Setting}

Several sedimentary environments have been identified in Pebas strata. These include distal bay (i.e., distal position in a large, quiescent embayment), bay margin, deltaic, tidal channel, lagoonal, and backshore/nonmarine deposits (Räsänen et al. 1998). Individual parasequences are generally less than $10 \mathrm{~m}$ thick and are typically capped by lignites or rooted lignites (Fig. 2). Flooding surfaces (FS) directly overlie the lignites and are normally demarcated by a transgressive surface of erosion (TSE, Fig. 2).

Fossils recorded from the Pebas Formation include the bones and teeth of nonmarine turtles, alligators, and fish (Monsch 1998; Gaffney et al. 1998). Fossils with a marine affinity, generally shark's teeth, have also been collected (Rancy 1991; Monsch 1998). An abundant mollusk fauna has been interpreted to reflect predominantly lacustrine conditions with episodic marine incursions (Vonhof et al. 1998)

\section{Methods}

Sedimentological and ichnological data were gathered through detailed descriptions of the parasequences. Sedimentary texture, sedimentary structure, nature of bedding and bedding contacts, fossil content, and lateral variability were documented. Ichnological observations concentrated on the identification of ichnogenera, the intensity of bioturbation, and the distribution of ichnofossils and ichnofossil assemblages. The size of the trace 


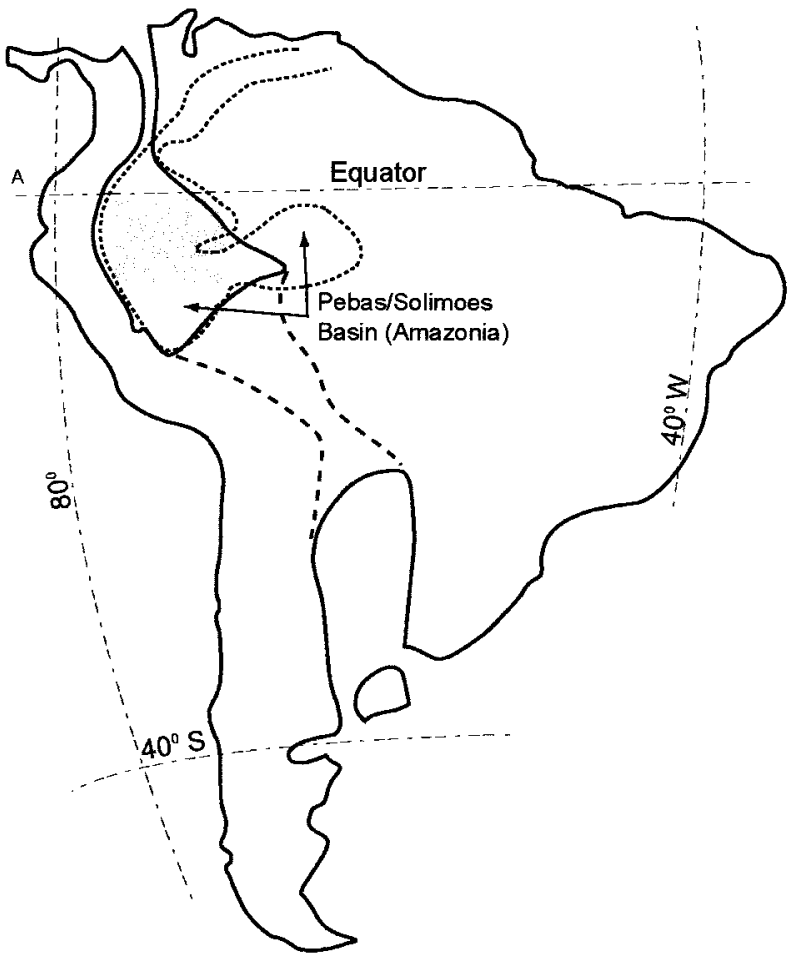

\section{' Potential Seaway Connection - Limits of Miocene South America Inset Map Area (B)}

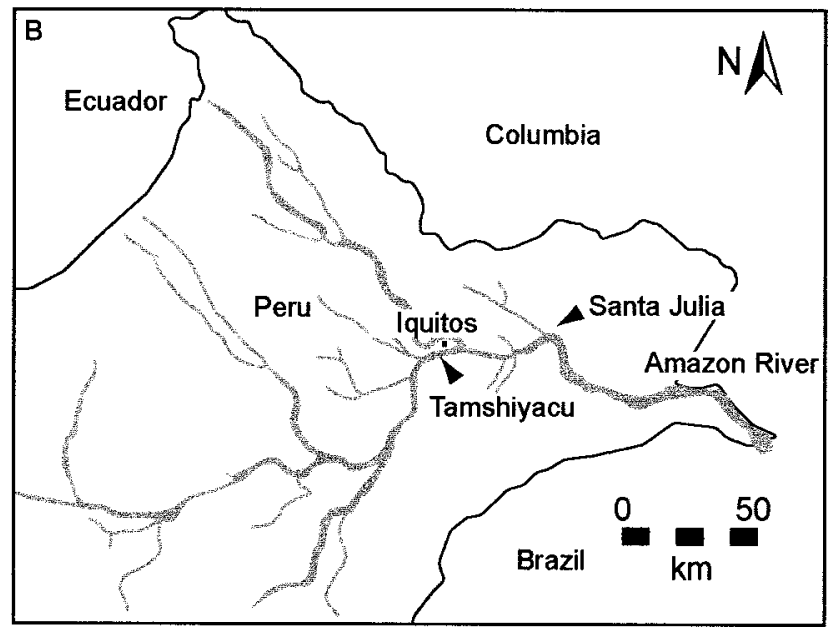

FIG. 1.-Location map showing the area encompassed by the Pebas-Solimöes (Miocene) sedimentary basin. Study localities (Santa Julia and Tamshiyacu) are indicated in the inset map. Also shown is the potential extent of a Miocene seaway as taken from Räsänen et al. (1995). fossils, and their physical interrelationships (such as interpenetrating, intercalated, or isolated occurrences) were also noted. The unlithified nature of the sediment made it difficult to observe bedding planes and hindered the identification of ichnogenera.

Some ichnological data was semiquantitative. For example: (1) the degree of bioturbation varies from nonbioturbated to completely bioturbated, and (2) trace-fossil distribution is sporadic (unpredictable), intercalated (associations of trace fossils that are juxtaposed in interbeds), or exist as recurring assemblages (ichnofossil assemblages that bioturbate beds). Other data, particularly trace-fossil size (generally tube diameter) and depth of penetration, were derived from averages of field measurements (generally $n=5$ to 15$)$.

\section{RESULTS}

\section{Sedimentary Facies}

On the basis of sedimentological and ichnological criteria, the Pebas Formation strata presented in this study show nine recurring sedimentary facies (Table 1). Table 1 outlines those criteria and offers a brief interpretation that relates to the facies' depositional significance.

\section{Sedimentary Succession at Santa Julia}

The strata at Santa Julia II consist of three coarsening-upwards successions (Parasequences A, B, and C; Figs. 2, 3). These are variously capped by erosional surfaces that can represent regressive, transgressive, or coplanar surfaces of erosion that are overlain by flooding surfaces. Those discontinuities are demarcated by burrowed horizons characteristic of the Glossifungites Ichnofacies (Frey and Seilacher 1980; Pemberton and Frey 1985; Pemberton and MacEachern 1995; Gingras et al. 2001). All of the parasequences are laterally continuous at the outcrop scale, showing no notable thickening or thinning.

Parasequence A (SJA).- At 0 m, a crudely laminated, locally muddy shell bed (F3B) comprising 70\% fragmented and 30\% nonfragmented gastropod shells is present. This is predominantly composed of Pebasian endemics such as Pachydon and Dyris spp. The shell bed is abruptly overlain by a nodular horizon that occurs within the horizontally laminated muds of F1A. Between 0.25 and $0.52 \mathrm{~m}$, the muddy accumulations are essentially nonbioturbated with the exception of rare Planolites. Lenticular shell-fragment laminae are common in this zone, and organic laminae are rare. Another nodular horizon is present at $0.45 \mathrm{~m}$.

At $0.52 \mathrm{~m}, \mathrm{~F} 1 \mathrm{~A}$ is scoured into by laminated sands $(\mathrm{F} 2 \mathrm{~A})$ that grade upwards into massive-appearing, bioturbated sands (F2B). A subtle increase in grain size accompanies the facies change, wherein the stratum coarsens from lower very fine-grained sand at $0.52 \mathrm{~m}$ to upper very fine-grained sand at $3.10 \mathrm{~m}$. Organic detritus and small mud fragments are common in this zone; both have $\mathrm{MnO}$ rinds $1 \mathrm{~mm}$ thick. Near $1.0 \mathrm{~m}$, pinstripe-laminated silty sand is weakly burrowed with Planolites (Fig. 3A). Sediment couplets are locally common. Between 2.50 and $3.10 \mathrm{~m}$, the ichnofabric consists of poorly defined tubular burrows, probably Thalassinoides (Fig. $3 \mathrm{~B})$. Facies $2 \mathrm{~B}$ is crosscut by rhizoliths that descend from the overlying lignite (F3A), and by well-defined, unlined Thalassinoides suevicus that crosscut F3A and F2B. Santa Julia A is ultimately capped by the aforementioned rooted lignite (F3A; 3.10 to $3.25 \mathrm{~m}$ ). At this location, the lignite is crudely horizontally laminated and contains several peat clasts.

Parasequence B (SJB).-A Glossifungites-demarcated discontinuity (F3C) denotes the base of Santa Julia Parasequence B (3.25 m). The ich-

FIG. 2.-Detailed lithologic logs of the sedimentary successions described or measured at the study localities. Physical and biogenic sedimentary structures are detailed in the lithology column. The green bars adjacent to the logs indicate facies that indicate a brackish-water interpretation. Note the repetitive sedimentary successions and the overall thinnesses of the parasequences. 

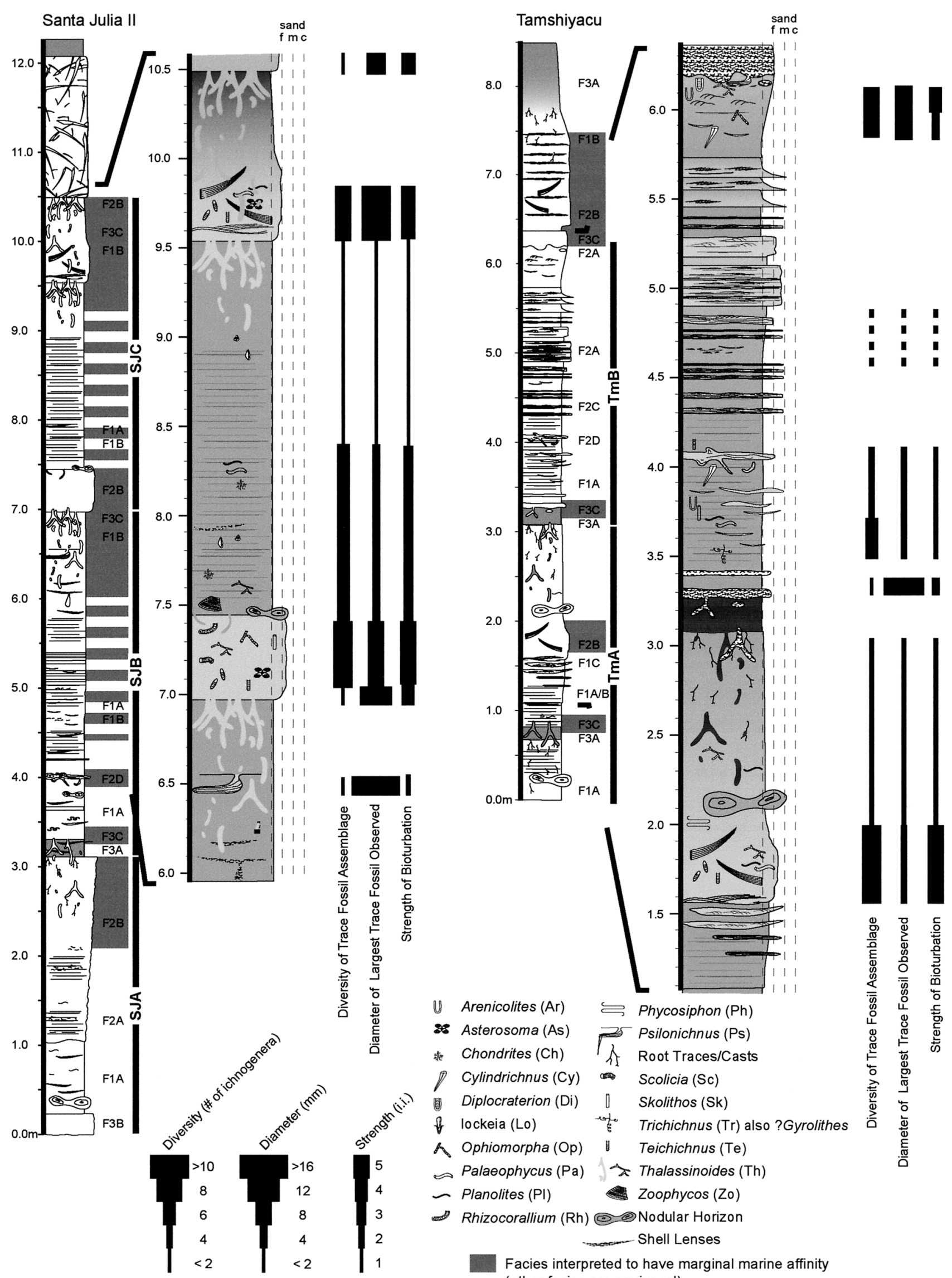
nofauna are composed solely of 10 to $16 \mathrm{~mm}$ diameter branching Thalassinoides suevicus, which extend $70 \mathrm{~cm}$ into the underlying stratum (lignite overlying massive sand). The ichnofossils crosscut in situ rhizoliths. Massive blue-gray mud, identical to the overlying unit (F1B), infills the trace fossils. The massive-appearing, locally burrowed muds intercalate upwards with laminated muds (F1A). Facies $1 \mathrm{~A}$ is the dominant facies between 4.20 and $5.80 \mathrm{~m}$, above which F1B is increasingly dominant. Between 3.25 and $5.80 \mathrm{~m}$, lenticular shell-fragment lenses and starved oscillation ripples are moderately abundant, particularly near 3.45 and $4.60 \mathrm{~m}$. Organic laminae increase in abundance upwards. Rare disarticulated bivalve shells and nonfragmented gastropod shells are disseminated throughout the interval. Bioturbation is absent to rare, though a few thin-bedded, moderately to highly bioturbated zones are locally intercalated. Where present, the ichnofauna are mostly composed of Chondrites-reburrowed Planolites. Rare, sporadically distributed, diminutive Planolites and Palaeophycus are observed as well. At $4.05 \mathrm{~m}$, a single, low angle cross-laminated bed contains Arenicolites at its base.

Facies 1B comprises the upper part of Parasequence B (5.80 to $6.95 \mathrm{~m}$ ). It is similar to the lower massive-appearing muds, except that it is locally sandier and some larger trace fossils are present. Trace fossils include largediameter $(>25 \mathrm{~mm})$ Psilonichnus that have a rhythmically laminated, passive infill, and tubular? Thalassinoides that are infilled with fragmented shells (hitherto referred to as shell nests). In addition, large sand-filled Thalassinoides crosscut this facies and represent a Glossifungites-demarcated discontinuity that is described below.

Parasequence $\mathbf{C}$ (SJC).-A burrowed, erosional contact (at $7 \mathrm{~m}$ ) defines the base of the cycle. At this level, the ichnofauna comprise large diameter ( $>10 \mathrm{~mm}$ ), unlined Thalassinoides that descend up to $80 \mathrm{~cm}$ below the erosional surface. Rarely, the ichnofossils contain a rhythmically laminated infill that defines discrete couplets (Fig. 3C).

Silty, fine-grained sand is present from 7.0 to $7.4 \mathrm{~m}$. It is highly bioturbated (ichnofabric index, i.i. 4 to 5) and the original physical sedimentary character is no longer evident (F2B). Trace fossils are large (3 to $15 \mathrm{~mm}$ diameter) and several ichnogenera are present, including Teichichnus, Thalassinoides, Ophiomorpha (O. irregulaire), Rhizocorallium, Planolites, Asterosoma, Scolicia, and Skolithos (Fig. 3D, E).

At $7.4 \mathrm{~m}$, muddy sand passes abruptly into burrowed mud (F2B) that is increasingly well laminated (F1B) between 7.5 and $9.5 \mathrm{~m}$. The base of F2B is burrowed with a suite of diminutive (1 to $3 \mathrm{~mm}$ diameter) Skolithos and Arenicolites. Above $7.5 \mathrm{~m}$, the physical sedimentary structures include pinstripe lamination and rare, low angle cross-lamination. Locally, shell lenses are present consisting of concave-up valves, and abundant fragmented and abraded mollusk shell fragments. As above, the shells primarily represent Pebasian endemics, including Pachydon and Dyris spp. Individual articulated bivalves are rare. A manganese-rich nodular horizon is present near the base of the mud $(7.5 \mathrm{~m})$. A stressed suite of small-diameter $(<2 \mathrm{~mm})$ trace fossils is attendant, including Chondrites-burrowed Planolites and $\mathrm{Pa}$ laeophycus, with very rare Zoophycos and small Thalassinoides.

At $9.5 \mathrm{~m}$ bioturbated, fine-grained sand sharply overlies the muds. A Glossifungites assemblage comprising Thalassinoides is present at the base of the sand. Rare, low-angle cross lamination is also evident. From 9.5 to $10.0 \mathrm{~m}$, trace fossils commonly exceed $10 \mathrm{~mm}$ diameter, and the sediment exhibits a higher degree of biogenic amalgamation (i.i. 4 to 5) and a greater number of ichnogenera. Teichichnus, Planolites, Palaeophycus, and Thalassinoides dominate this trace assemblage (Fig. 3F). Smaller trace fossils are present, but their taxonomy is uncertain. From 10.0 to $10.5 \mathrm{~m}$, the sand grades into massive-appearing organic mud. Root traces are absent, and a sandy stratum erosionally overlies the mud.

\section{Sedimentary Succession at Tamshiyacu}

The strata at Tamshiyacu consist of two coarsening-upwards successions (Parasequences A and B; Figs 2, 4). The parasequences are capped either by erosional surfaces or by lignites. Glossifungites-demarcated discontinuities (cf. Frey and Seilacher 1980; Pemberton and Frey 1985; Pemberton and MacEachern 1995; Gingras et al. 2001) are present at the bases of Parasequences A and B; these are composed solely of Thalassinoides.

Parasequence A (TmA).- - The base of Parasequence A (0.82 to 3.30 $\mathrm{m}$ ) is situated immediately above a lignite that denotes the top of an underlying parasequence. Several large-diameter Thalassinoides descend from the contact. The ichnofossils and their sedimentological occurrences are similar to the previously described examples of the Glossifungites Ichnofacies (F3C). Above the contact, laminated, rarely burrowed mud (F1A) grades into laminated mud with starved current ripples. Rare Chondritesreburrowed Planolites are observed near $0.90 \mathrm{~m}$ (Fig. 4A). Near $1.25 \mathrm{~m}$, however, F1A grades into nonburrowed, horizontally bedded sand and mud (F2C). Interbeds are composed of current rippled sand with abundant organic detritus on ripple foresets.

At $1.57 \mathrm{~m}$, a sharp, undulatory contact is encountered, marking the base of a moderately to highly bioturbated sand. At the base of the sand, low angle cross-lamination, and small-scale $(60-100 \mathrm{~cm}$ hummock spacing) hummocky cross-stratification is present. The laminated bed is only 4 to 5 $\mathrm{cm}$ thick, and it rapidly grades into upwards-fining, bioturbated silty sand (F2B; $1.65-2.10 \mathrm{~m}$ ). Although biogenic churning lends the sand a rather massive appearance, several ichnogenera are observed nevertheless. These include: common, broad, large-diameter Teichichnus; small, rare Thalassinoides (Fig. 4B); common, small Planolites and Palaeophycus (Fig. 4B); and nearer $2.10 \mathrm{~m}$, rare Helminthopsis. Teichichnus clearly crosscuts the suite of trace fossils, but the other trace-fossil interrelationships are unclear.

Ironstone nodules are present near $2.15 \mathrm{~m}$; these can be traced along the length of exposure. Above the nodular horizon, the stratum comprises massive-appearing muds of F1B. The lithofacies extends from 2.15 to $3.08 \mathrm{~m}$. The only visible trace fossils in this unit are small, moderately abundant Planolites and very rare Thalassinoides. Although the massive appearance of the mud suggests that the bioturbation intensity is high, the local paucity of individual trace fossils makes this difficult to assess. Facies 1B is crosscut by roots that descend from the overlying lignite. Also, two Glossifungites associations crosscut F1B; (1) a suite of large diameter (15 to $20 \mathrm{~mm}$ ) Thalassinoides that extend from the lignite, and are infilled with lignite, and; (2) shell-filled Thalassinoides that connect to a shell bed situated on top of the lignite, clearly crosscutting the lignite-filled burrows. For reasons presented in the discussion, the lignite bed is interpreted to form the base of Parasequence B. Thereby, the top of Parasequence A occurs at $3.08 \mathrm{~m}$.

Parasequence B (TmB),- Parasequence B extends upwards from 3.08 to $6.40 \mathrm{~m}$ (Fig. 4D-F). The base of the succession is represented by a sharp contact between laterally discontinuous lignite and the underlying mud. A well-developed Glossifungites assemblage is present at the base of the organic bed (F3C; Fig. 4D).

Above the lignite $(3.3 \mathrm{~m})$, a shell bed 8 to $12 \mathrm{~cm}$ thick is present $(\mathrm{F} 3 \mathrm{~B})$. The shells are derived from various mollusks and have endured varying degrees of fracture and abrasion. Few are observed in their "normal" living position. Like the lignite, the base of this bed is burrowed with Thalassinoides and Psilonichnus characteristic of Facies 3C. In this example, the burrows are filled with shells and the ichnofossils clearly crosscut the lower, lignite-filled Thalassinoides.

Gray to brown clay is observed immediately above the shell bed, the lowermost part of which is laminated F1A. At $3.5 \mathrm{~m}$, lenticular sand is present; starved ripples increase in breadth and thickness upwards. These grade into $\mathrm{F} 2 \mathrm{C} / \mathrm{D}$, locally burrowed, interlaminated and interbedded finegrained sand, at approximately $4.0 \mathrm{~m}$. Sand interbeds are planar to oscillation-ripple laminated. Mud drapes are abundant.

From 3.5 to $4.1 \mathrm{~m}$, the degree of bioturbation is low (i.i. 1 to 3). Several ichnogenera are present, including Planolites, Palaeophycus, Skolithos, Arenicolites (Fig. 4E), Gyrolithes, and rare Cylindrichnus. Variable and chaotic ?Trichichnus are also present. Burrows associated with the muddier sediment are small $(<3 \mathrm{~mm}$ diameter), and those descending from sand 
TABLE 1.-Summary of facies used in this investigation to characterize Pebas Formation strata.

\begin{tabular}{|c|c|c|}
\hline Description & Occurrence and Contacts & Sedimentology/Accessories \\
\hline $\begin{array}{l}\text { F1A } \\
\text { Laminated Mud } \\
\text { (very common facies) }\end{array}$ & $\begin{array}{l}\text { - normally directly above ravinement } \\
\text { (represented by F2B); less commonly } \\
\text { sharply overlies F3A, F3B or F3C } \\
\text { - gradational with F1B, F2C, and F2D } \\
\text { - typically observed near the middle of } \\
\text { parasequences }\end{array}$ & $\begin{array}{l}\text { - horizontally laminated mud with abun- } \\
\text { dant, thin, organic laminae } \\
\text { - rare, thin, lenticular, shell and/or sand } \\
\text { laminae } \\
\text { - wood clasts; rare detrital amber } \\
\text { - rare sand/mud couplets } \\
\text { - may contain nodular horizons }\end{array}$ \\
\hline $\begin{array}{l}\text { F1B } \\
\text { Bioturbated Mud } \\
\text { (very common facies) }\end{array}$ & $\begin{array}{l}\text { - directly and abruptly above TSE (F3B } \\
\text { and F3C) and ravinement (represented } \\
\text { by F2B) } \\
\text { - gradational with F1A and F2D } \\
\text { - most common in the lower third of } \\
\text { parasequences }\end{array}$ & $\begin{array}{l}\text { - massive-appearing mud with inter- } \\
\text { spersed organic detritus } \\
\text { - sand and shell-debris sporadically dis- } \\
\text { tributed throughout the deposit } \\
\text { - wood clasts } \\
\text { - may include thin, horizontally lami- } \\
\text { nated horizons } \\
\text { - nodular horizons normally absent }\end{array}$ \\
\hline
\end{tabular}

F2A

Laminated Sand (common facies)

Bioturbated Sand (common facies)

F2C

Interbedded Sand/Mud (unburrowed) (common facies)

F2D

Interbedded Sand/Mud (burrowed) (rare facies)

F3A

Lignite/Organic Mud

(common facies)

F3B

Mollusk Shell Beds/Lags (common facies) generally present in the upper third of parasequences

- shares abrupt contacts with F2B

- generally F2A sharply overlies other facies

- may grade from F2C

- normally at the base of, or capping, parasequences

- sharply overlies F3C

- may have an abrupt contact with F3A

- mostly occurs in the upper half of parasequences

- in general $\mathrm{F} 2 \mathrm{C}$ is gradational with F1A and $\mathrm{F} 1 \mathrm{~B}$, but it has been observed to grade into F2A

- mostly occurs in the upper half of parasequences

- in general F2D is gradational with F1A and F1B

- F2D has been observed to grade into F2A and F2B

- caps parasequences (regressive)

- locally forms in association with TSE

- typically has sharp upper and lower contacts

- may appear gradational with F2A and F2B due to rhizoturbation

- caps parasequences and locally forms in association with TSE

- commonly associated with F3A ripple (wave and current) laminated sand intercalated with horizontal to wavy-parallel lamination

- composed of fine-grained, lithic arenite

- small clay ripup clasts common

- rare shell detritus

- common Mn oxide around organic detritus

- bioturbated, locally massive-appearing sand

- composed of fine-grained, lithic to feldspathic arenite

- common Mn oxide around organic detritus and some trace fossils

- sedimentary couplets preserved as burrow infills (tubular tidalite)

- ripple (wave and current) laminated sand intercalated with horizontal to ded with horizontally laminated, locally organic rich mud

- horizontally bedded in the study area

- common pinstripe lamination and sedimentary couplets

- ripple (wave and current) laminated sand intercalated with horizontal to wavy-parallel lamination and interbedded with horizontally laminated, locally organic rich mud

- horizontally bedded in the study area

- common pinstripe lamination and sed-

imentary couplets

- massive appearance

- wood clasts are imbricated and define

low angle bedding

- in situ root fossils are observed beneath most of the lignites

- crudely horizontally laminated, locally cross-laminated

- locally mud-supported wavy-parallel lamination and interbed-

- locally horizontally laminated
- absent to rare bioturbation

rare ichnofossils include Skolithos. Planolites, and Arenicolites

- rare, unfragmented gastropod shells

common, diminutive trace fossils that disrupt physical lamination along discrete horizons

- trace fossils consist of common Skolithos, Arenicolites, and Gyrolithes; rare Cylindrichnus, Thalassinoides and Psilonichnus

- rare, unfragmented gastropod shells

- either unburrowed or is almost completely burrowed by large Thalassinoides and Psilonichnus.

- burrow fills commonly contain abundant fragmented mollusk shells

- rare to moderate Psilonichnus and Thalassinoides that descend from shell beds and are filled with shells

- generally dominated by partially fragment mollusk shells (previously interpreted as lacustrine to oligohaline)

- consists of robust, unlined burrows that descend from a discrete horizon; the burrows are filled with sediment derived from the overlying stratum

- robust Thalassinoides, Psilonichnus, and Arenicolites variable sedimentology; ichnofacies dependant

sedimentary couplets preserved as burrow infills (tubular tidalite)
Interpretation

- low hydraulic energy, deposition primarily from suspension

- rare energetic events are indicated by sand and shell laminae

- bottom conditions stressed, possibly due to turbidity, dysaerobic botton water, salinity fluctuation or a combination of these factors

- low hydraulic energy; deposition primarily from suspension

- rare energetic events are indicated by disseminated sand and shell debris

- bottom conditions are stressed, but (unlike F1A) the physicochemical parameters afford colonization by infauna

- the impoverished ichnofauna probably reflects low dissolved oxygen content in the water: oxygen levels were stable and mixing of basin waters occurred

- salinity stress may also influence the trace-fossil assemblage

- prevalent modes of sediment transport are as bedload due to bottom currents; locally reworked by waves

- F2A's position in parasequences (upper half), in conjunction with the inferred transition to higher hydraulic energy, evidence shoaling

- stressful physicochemical conditions due to shifting substrate, low overal salinity, or fluctuating salinity

- sediment transport mechanism unclear due to biogenic reworking

- sharp base implies energetic emplacement of the sand

- subsequent hydraulic reworking minimal, affording biogenic modification of sand

- almost marine salinity, well oxygenated

- tidal processes indicated by tubular tidalites

- prevalent modes of sediment transport are as bedload due to unidirectiona currents, locally reworked by waves; mud deposited from suspension or as flocculated mud

- stressful physicochemical conditions due to lithological heterogeneity, low overall salinity, and/or fluctuating salinity

- prevalent modes of sediment transport are as bedload due to unidirectional currents and by waves; mud deposited from suspension or as flocculated mud

- typical brackish-water assemblage (fluctuating salinity and/or low salinity)

- where capping parasequences and is overlain by the Glossifungites ichnofacies, F3A is interpreted to form in marshes during lowstand of relative sea level

- where F3A overlies the Glossifungites Ichnofacies, it is thought to form in association with TSE

- derived from wave- and current-winnowed shell beds that accumulated in quiescent ponds in a discrete backshore (marsh) position

- locally, may represent episodic basinward transport induced by meteoric events, causing intense runoff and coastal setup

- suggests change in local base level; commonly referred to as a Glossifungites-demarcated discontinuity

- associated with TSE 

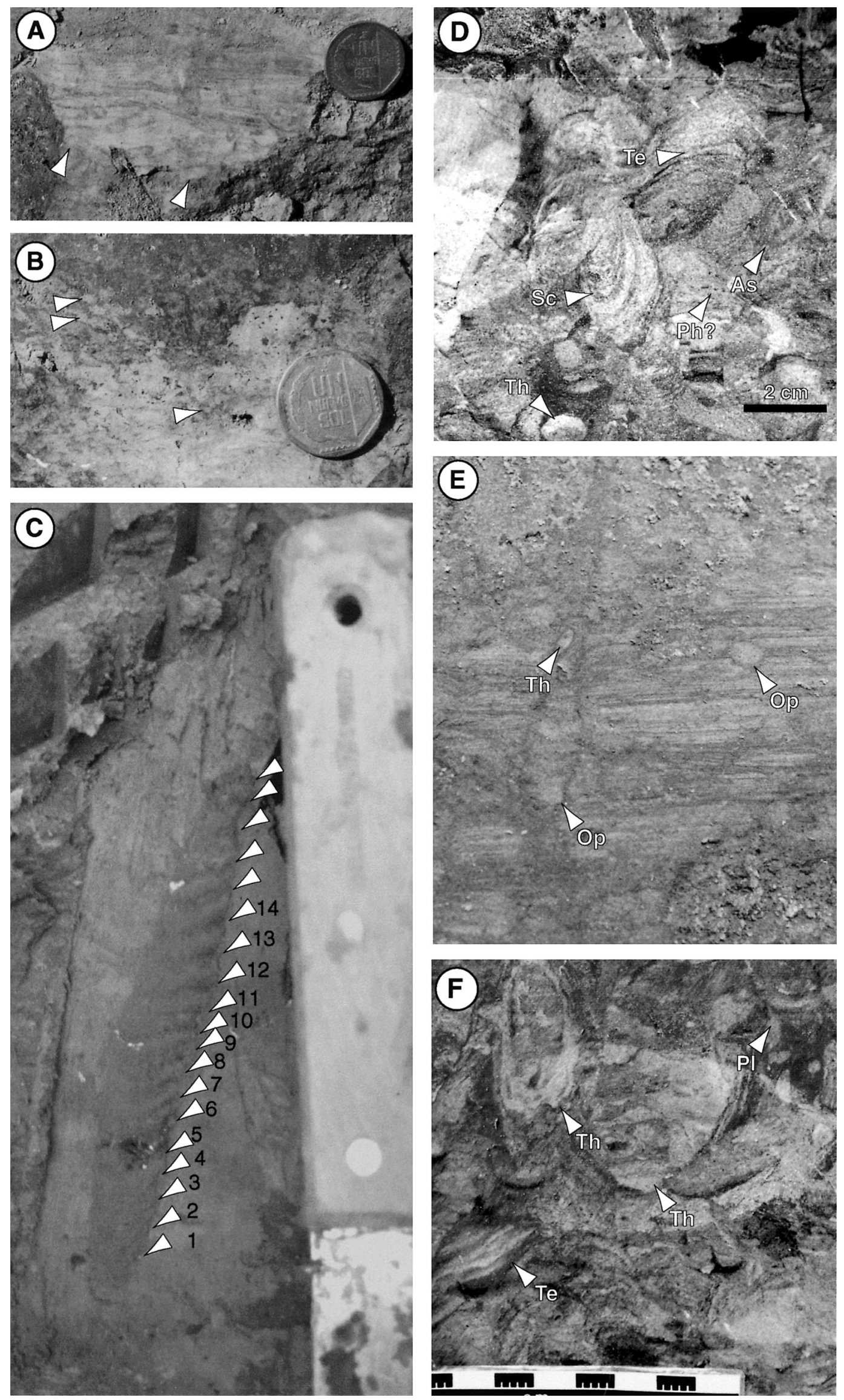
interbeds are moderate in size ( 3 to $5 \mathrm{~mm}$ diameter). Trace fossils associated with sand interbeds are restricted to Skolithos and Arenicolites. Pinstripe lamination and organic couplets are very common (Fig. 4E, F).

Above $4.10 \mathrm{~m}$ (to $5.28 \mathrm{~m}$ ), the sedimentary succession continues to coarsen upwards. Mud intercalated with sand grades to bedded sands of F2A. These are dominated by oscillation-ripple lamination. Clay drapes are common. Trace fossils are absent in this zone. An abrupt shift to F2A occurs at $5.28 \mathrm{~m}$. The laminated, nonburrowed sand and mud contains abundant organic detritus and rare shelly debris. The sand beds are sharpbased, current-ripple laminated and low-angle cross laminated. Several of the sand beds are normally graded and terminate in silty mud. Capping parasequence B is a coarsening-upwards, burrowed bed containing Cylindrichnus, Arenicolites, and Ophiomorpha. Near $6.0 \mathrm{~m}$, this bed comprises burrowed, ripple-laminated silty sand.

\section{INTERPRETATION OF THE SEDIMENTARY SUCCESSIONS}

\section{Glossifungites Ichnofacies in the Pebas Formation}

Four of the five parasequences described in this study are demarcated at their bases by the Glossifungites Ichnofacies (SJB, SJC, TmA, and TmB). All of the surfaces possess tubular, branching, moderate to large diameter (10-25 mm) Thalassinoides suevicus. In addition, firmground Psilonichnus upsilon is reported from the base of TmA and SJC. In all of the examples, the trace fossils crosscut rhizoliths, are unlined, and are infilled with overlaying sediment. Thalassinoides and Psilonichnus observed in two of the parasequences (SJB and C) locally contain passively laminated, rhythmic infill, in which sedimentary couplets are preserved (Fig. 3C). The couplets are regularly asymmetric and are taken to be the result of tidal processes infilling abandoned burrows.

The Glossifungites Ichnofacies consists of burrow architectures and sedimentological relationships that demonstrate burrowing into a firm substrate. The widespread exposure of firm (compacted) sediment requires erosion of previously buried sediment, due to changes in local base level. Such changes are most commonly attributed to fluctuations in sediment supply, subsidence/uplift, autocyclic avulsion (such as delta-lobe or channel abandonment), or eustatic adjustment. Where Glossifungites-demarcated surfaces are widespread, mappable, and recurrent in the stratigraphic succession, their presence is generally attributed to changes of relative sea level. Several researchers have demonstrated the importance of identifying Glossifungites Ichnofacies assemblages in the rock record, inasmuch as they are commonly associated with transgressive surfaces of erosion (TSE) (Pemberton and Frey 1985; Pemberton and MacEachern 1995; Gingras et al. 2001; Savrda et al. 2001).

In the Pebas Formation, Thalassinoides are attributed to the work of thalassinid shrimp; this interpretation is based on the presence of complex subaperture geometries that are common in thalassinid burrows but are absent in the burrows of other crustaceans (Gingras et al. 2000). Relating these burrows to the work of thalassinid shrimp is well supported by several modern and ancient studies (Shinn 1968; Rice and Chapman 1971; Frey and Howard 1975; Frey et al. 1978; Dworshak 1983; Griffis and Chavez 1988). Furthermore, the irregular burrows of crabs, lobsters, and crayfish are equally well known, and they characteristically have simple U-, J-, or
Y-shaped subapertures with rare or no basal branching (Farrow 1971; Atkinson 1974; Humphreys and Balson 1988; Hasiotis and Honey 2000; Gingras et al. 2001).

On the basis of the presence of Thalassinoides, Glossifungites Ichnofacies assemblages of the Pebas Formation are interpreted to have a marginal marine affinity. The occurrence of the Glossifungites Ichnofacies at the bases of parasequences, their marginal marine affinities, and the presence of rhythmic burrow fills suggest that the Pebas examples represent TSE in a brackish-water setting (Fig. 5A, discussed below). An exception to this is the Glossifungites Ichnofacies assemblage that is reported near the top of SJC. In that case, the ichnofossils are interpreted to have been emplaced upon the erosional progradation of the bay margin into the embayment (Fig. 5B, discussed below).

\section{Santa Julia}

Interpretation of Parasequence A (SJA).-Santa Julia A (0-3.25 m) is initiated with a sharp-based bed of partially fragmented shells. Although the degree of fragmentation is high, abundant, intact gastropod shells suggest that the shells are more or less in situ, and thereby represent a reworked, winnowed accumulation of skeletal debris. Crude, horizontal, muddy laminae within the shell bed indicate that the bed represents an amalgamation of several higher-energy events. The absence of high-angle cross lamination within the bed is indicative of wave- as opposed to currentreworking. Vonhof et al. (1998) show that the shelly fauna consistently represents a fresh to low-salinity epifaunal assemblage of mollusks. The shell bed is therefore interpreted to represent in situ wave reworking of a lagoonal or backshore deposit upon transgression. The overlying muds of F1A represent incursion of embayment waters across the area. The sedimentary environment was characterized by low hydraulic energy, but lenticular shell laminae suggest that episodic, basinward transport of detritus was common. The low-diversity and rare ichnofauna (primarily Planolites) in SJA, support stressful physicochemical conditions, which may reflect: (1) fresh water, or very low salinity; (2) widely fluctuating salinity; (3) low amounts of dissolved oxygen in the water column, and/or; (4) a turbid water column. The highly restricted trace-fossil assemblage is not consistent with ichnofabrics produced due to salinity stress alone, which includes (among other criteria), locally high degrees of bioturbation, marine trace fossils, and a mix of suspension and deposit feeding strategies (Pemberton et al. 1982). The assemblage is also dissimilar to the Chondrites-dominated ichnofabrics that are strongly associated with low oxygenation in marine settings (e.g., Savrda and Bottjer 1989; Sageman et al. 1991). Rather, the abundance of fine-grained sediment and the extensive use of a depositfeeding strategy, coupled with a very low diversity of ichnofossils, are more consistent with stresses induced by turbid water in a salinity-stressed environment (Gingras et al. 1998).

Coarser sediment erosionally overlies the weakly burrowed muds. Although cross lamination is rare, the increase in grain size, abundant mud ripup clasts, and the erosional contact indicate an increase in hydraulic energy. The more abundant organic detritus is consistent with a proximal position to the paleoshoreline. The transition to bioturbated sand suggests that bottom conditions were amenable to colonization. Strata between 1.05

$\leftarrow$

FIG. 3.-Selected ichnofacies from Santa Julia. A) Thalassinoides (white arrows) in a pinstripe laminated muddy sand (SJA, 1.05 m). The coin is 25 mm in diameter. B) Planolites-mottled muddy sand. Discrete burrows indicated with white arrows (SJA, $2.60 \mathrm{~m}$ ). The coin is $25 \mathrm{~mm}$ in diameter. C) Thalassinoides infilled with paired laminae. Although they are all paired (visible at \#15), the uncemented sediment smeared too easily during excavation for proper documentation. These are interpreted to have accumulated inside the burrow in concert with tidal (semidiurnal) processes. Approximately fourteen laminae sets are counted between the thickest preserved sets; these straddle the thinnest laminae (SJC, $6.8 \mathrm{~m}$ ). Knife handle is $18 \mathrm{~cm}$ long. D) Complex ichnofabric from SJC (7.2 m). A variant of Scolicia (Sc), Asterosoma (As), Thalassinoides (Th), ?Phycosiphon (Ph?), and a large Teichichnus (Te) are indicated. Several other trace fossils are present, notably Planolites. E) Ophiomorpha (Op) crosscutting tidally generated (?) pinstripe laminae (SJC, $7.40 \mathrm{~m})$. F) Complex ichnofabric dominated by Teichichnus (Te), Thalassinoides (Th), and Planolites (Pl). Santa Julia, $9.7 \mathrm{~m}$. 

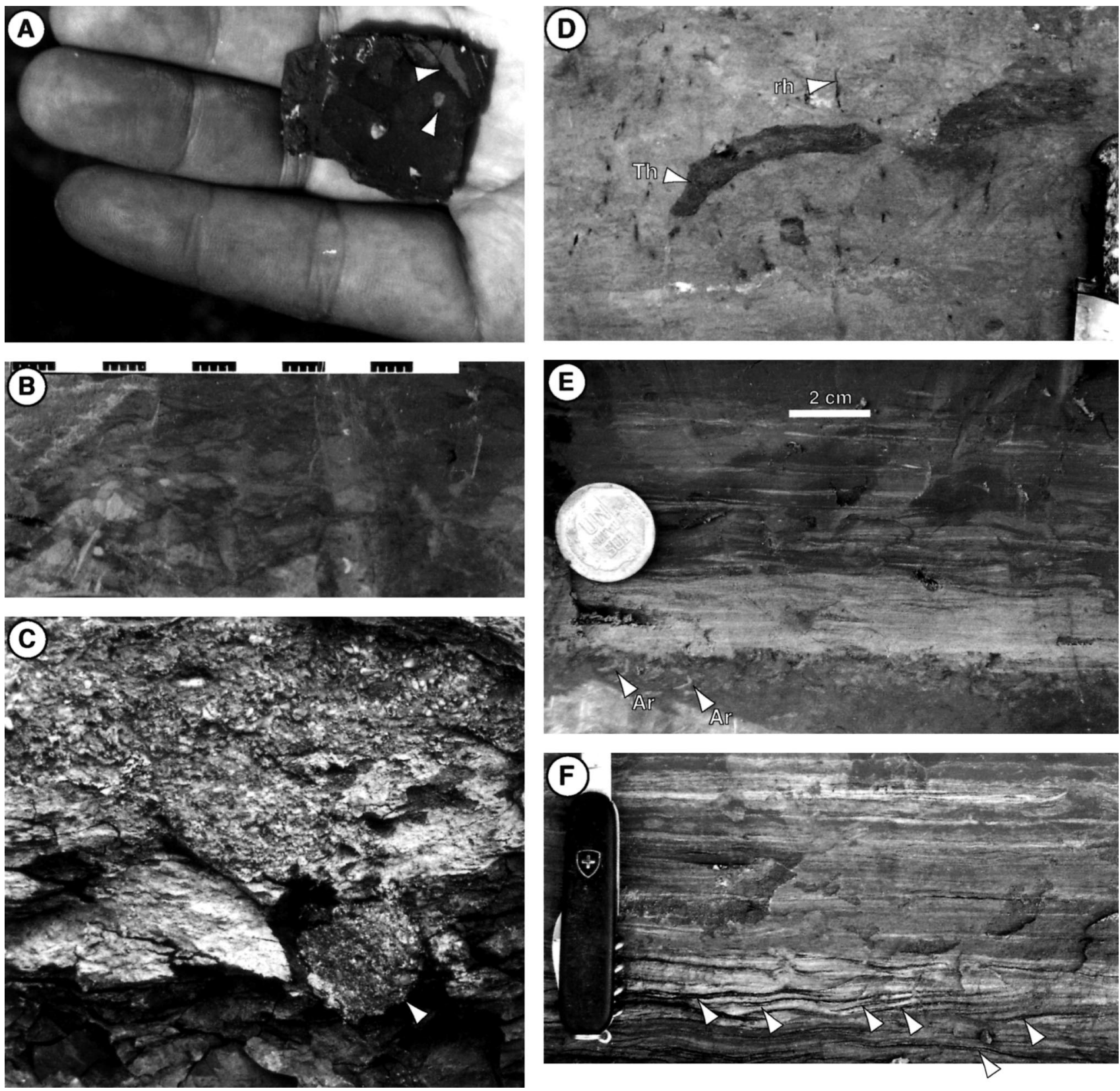

FIg. 4.-Selected ichnofacies from Tamshiyacu. A) Chondrites reburrowing Planolites in massive-appearing mud. Note the small burrows (Chondrites) that look like seeds around the main burrow of Planolites (white arrows) (TmA, $0.9 \mathrm{~m}$ ). B) Thalassinoides ichnofabric with $\mathrm{cm}$ scale (TmA, $1.7 \mathrm{~m})$. C) Psilonichnus in cross section that represents part of the Glossifungites Ichnofacies (TmB, $3.3 \mathrm{~m}$ ), The burrow is $9 \mathrm{~cm}$ in diameter. D) Thalassinoides (Th) infilled with organic mud from the overlying contact. Several rhizoliths $(\mathrm{Rh})$ are present. They are crosscut by the trace-fossil assemblage, which is interpreted to comprise the Glossifungites Ichnofacies (TmB, 3.3 $\mathrm{m})$. The knife handle is $16 \mathrm{~cm}$ long. E) Monospecific suite of Arenicolites at the base of a sand laminae set (TmB, $4.1 \mathrm{~m})$. Ophiomorpha is $23 \mathrm{~mm}$ in diameter. F) Organic detritus defines couplets on ripple foresets (white arrows) $(\mathrm{TmB}, 5.4 \mathrm{~m})$. The knife handle is $11 \mathrm{~cm}$ long.

and $2.00 \mathrm{~m}$ are highly bioturbated with a low-diversity trace-fossil assemblage (Fig. 3A, B). Similar ichnofabrics are related to physicochemical stresses induced by: (1) low overall salinity and/or (2) widely fluctuating salinity (Pemberton et al. 1982; Beynon and Pemberton 1992; MacEachern and Pemberton 1994; Ranger and Pemberton 1997; Gingras et al. 1999). The overlying, peaty lignite represents accumulation of organic material in a swamp or marsh, backshore setting. In situ root traces attest to this interpretation.

Interpretation of Parasequence B (SJB).-The base of SJB (3.25 m) comprises a Glossifungites demarcated discontinuity interpreted to repre- sent a TSE in a marginal marine setting. Here, large Thalassinoides crosscut the SJA lignite, the rhizoliths associated with the lignite, and the bioturbated silty sand that is immediately below the SJA lignite. The firmground burrows are filled with mud derived from the basal part of SJB and locally are rhythmically infilled.

Immediately above the Glossifungites Ichnofacies, the mud is locally burrowed and dominantly horizontally laminated. Lenses filled with shell debris indicate rare higher-energy events that swept fragmented shells into an otherwise quiescent environment. Bioturbation is sporadically observed to $5.80 \mathrm{~m}$, and the trace-fossil assemblage displays a very low diversity. 


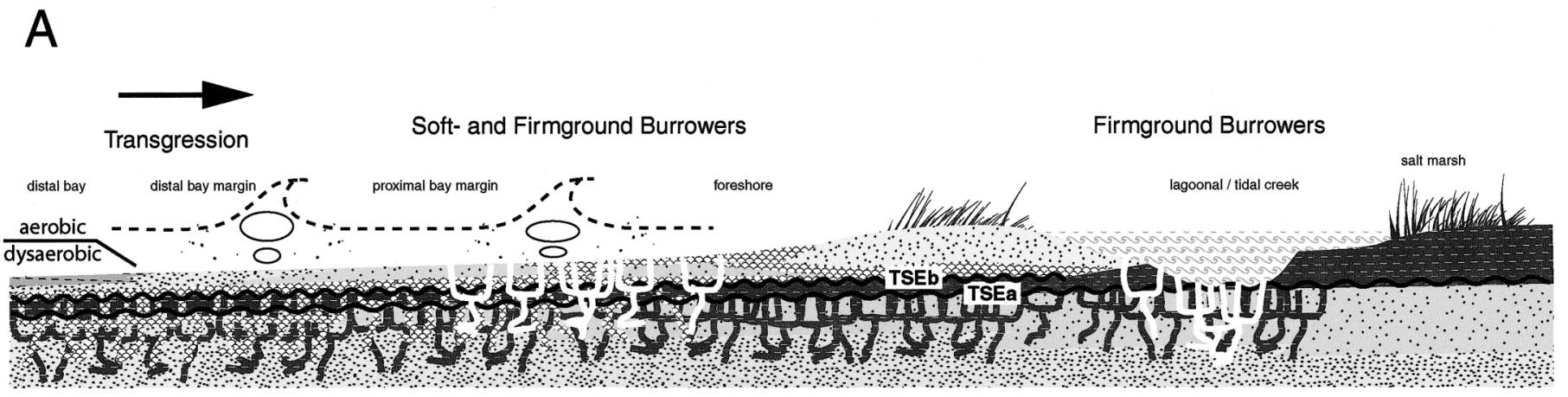

B

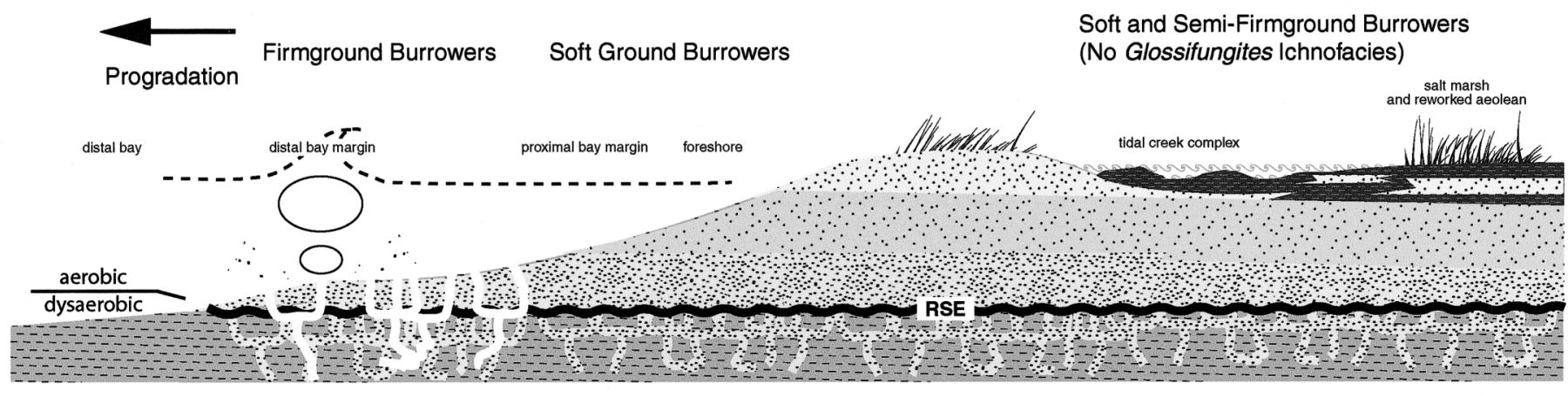

\section{$\therefore$ backshore sand}

$\because \because$ proximal bay margin sand

distal bay margin sand distal bay muds

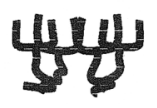

lagoonal muds / backshore peats

winnowed shell debris

FIG. 5.-Schematic interpretation of Pebas Formation bay-margin parasequences. A) Transgressive deposits may be characterized by tidal ravinement in the backshore and wave ravinement in the bay margin. This best explains the complex Glossifungites Ichnofacies association seen at the base of TmB. The lignite is inferred to have formed during transgression. Firmground burrowers are shown in the backshore and the foreshore. The backshore assemblage is characterized by burrows filled with lignite, and the foreground burrows are shell-filled. The shell material was winnowed from backshore deposits, explaining their low-salinity isotopic signatures. B) On regression, the toe of the bay margin erodes into the underlying distal bay sediments. Locally, the exhumed distal bay deposits host a firmground assemblage of the Glossifungites, as with SJC $(9.6 \mathrm{~m})$. Here it is suggested that the hydraulic action of the bay margin determines where the water is oxygenated and de-stratified.

Chondrites-reburrowed Planolites represent the dominant ichnofabric. The presence of Chondrites is notable because it is a common ichnofossil in marine deposits, especially in dysaerobic depositional settings (Savrda and Bottjer 1989; Sageman et al. 1991). The preservation of organic-rich laminae up to $5.80 \mathrm{~m}$ in the section also indicates that the water-sediment interface was dominantly dysaerobic; in fact, the presence of abundant organic material may have been the main agent causing low-oxygen conditions (Hollander et al. 1992; Cornwell et al. 1996).

Above $5.80 \mathrm{~m}$, the grain size increases slightly to silty (locally sandy) mud. Larger trace fossils, such as Thalassinoides and Psilonichnus, are an additional component of the ichnofabric, which is thoroughly bioturbated. The larger trace fossils represent the domiciles of crustaceans, which have normal oxygen requirements; thus stresses other than dysaerobic conditions influenced the ichnofacies. High degrees of bioturbation, low diversities of ichnofossils, and a preponderance of infaunal trophic generalists of a marine affinity are all characteristics of the brackish-water model initially articulated by Pemberton et al. (1982). Here, the trace-fossil assemblage indicates low overall salinity, or salinity fluctuations. The presence of rhythmic burrow infills organized in couplets suggests that tidal currents may have induced salinity fluctuation. The parasequence ends abruptly at
$6.95 \mathrm{~m}$. The top of the stratum was probably eroded, and the parasequence is incompletely preserved.

Interpretation of Parasequence C (SJC). - Santa Julia C is a crudely coarsening-upwards succession, with a thin, winnowed sandy horizon at its base. Bioturbation is common in the sandy beds and is comparatively sparse in the muddy beds. The parasequence is bounded at its top and base by Glossifungites-demarcated horizons, both of which are interpreted to represent marine-influenced TSE. The basal Glossifungites Ichnofacies assemblage locally contains rhythmically laminated infills (Fig. 3C) that potentially record tidal processes.

Highly bioturbated silty sand sits directly above the basal Glossifungites Ichnofacies (7.0 to $7.4 \mathrm{~m}$ ) (Fig. 3D, E). Trace fossils in the overlying sand, notably Ophiomorpha, Asterosoma, and Scolicia, show that marine conditions dominated at the time of sedimentation. The majority of Ophiomorpha are reported from marginal marine and marine deposits (Frey et al. 1978). Where Ophiomorpha is reported from nonmarine settings, such as by Loope and Dingus (1999), the dominant features of the ichnofossil are silt- and sand-ball linings, in stark contrast to the muddy fecal pellets that line marginal marine and marine Ophiomorpha. Asterosoma and Scolicia are reported only from marine deposits. Urchins, which are the only 
known trace maker of Scolicia (Smith and Crimes 1983), have no significant reduced salinity tolerance. As a whole, the trace-fossil assemblage in the silty sand (Teichichnus, Thalassinoides, Ophiomorpha, Rhizocorallium, Planolites, Asterosoma, and Skolithos) represents a proximal Cruziana Ichnofacies (Pemberton et al. 1992). Similar assemblages characterize the lower bay margin and proximal distal bay in Cretaceous rocks of the Western Interior Seaway (MacEachern and Pemberton 1992; Pemberton et al. 1992). The lowermost sand probably represents the churned remnants of the ravinement deposit associated with the marine transgression.

Locally bioturbated muds that lie immediately above the marine deposits signal a switch to a more quiescent and restricted depositional environment. Above $7.45 \mathrm{~m}$, pinstripe lamination may develop in response to weak tidal currents with shell lenses emplaced during higher energy events. Up to $8.40 \mathrm{~m}$ in the section, the Chondrites, Planolites, and Zoophycos-dominated ichnofabric is linked to both low levels of oxygen in the water column (Bromley and Ekdale 1984; Savrda and Bottjer 1989; Sageman et al. 1991) and quiescent depositional conditions; they are indicative of a marine, dysaerobic, sheltered, distal bay environment.

From $8.45 \mathrm{~m}$ to $9.5 \mathrm{~m}$, lower trace-fossil diversities, smaller trace-fossil sizes, and lower degrees of bioturbation all indicate that the sedimentary environment was increasingly dysaerobic upwards. An absence of silt or sand laminae, the massive and organic-rich appearance of the mud, and the absence of in situ bivalves support this interpretation.

Bioturbated sands (9.5 to $10.0 \mathrm{~m}$ ) (Fig. 3F) document the progradation of lower bay-margin sediments into the area. Roy et al. (1994) showed, with numerical models, that regressive bay-margin systems can be markedly and regionally erosive, especially if the depositional slope is shallow and accommodation space limited. Because the sand body does not directly overlie a sequence boundary, it is more likely that the unit represents rapid progradation of the bay margin in an area characterized by limited accommodation space, not a response to falling sea level, which would be manifested as a forced regression (Posamentier and Allen 1999). The base of the sands $(9.50 \mathrm{~m})$ is bioturbated by a Glossifungites Ichnofacies that locally contains rhythmic infill. The size and architecture of the Thalassinoides present indicate marine conditions, which is supported by the presence of Asterosoma in the softground suite above the contact. These sands ultimately grade into nonburrowed organic-rich muds. The muddy deposits are interpreted to reflect restricted lagoonal or a marsh or backshore environment. Because roots and paleosols are absent, the lagoonal interpretation is preferred. The lagoonal muds are truncated by an erosional surface and crosscut by a Glossifungites Ichnofacies assemblage.

\section{Tamshiyacu}

Interpretation of Parasequence A (TmA).-Like Parasequences SJB and SJC, Parasequence TmA has an erosional base that hosts a Thalassinoides-dominated Glossifungites assemblage. The ichnofossils are present at the bottom of the parasequence, and they are overlain by distal bay muds (see below); the assemblage is taken to have been emplaced during transgression, and thereby represents a TSE. The thin, discontinuous, shelly mud overlying the TSE is interpreted to have been winnowed from the underlying lignite facies during transgressive erosion. Directly above the shelly mud $(0.85 \mathrm{~m})$ is organic-rich, nonburrowed mud that is nonburrowed because of dysaerobic conditions. The grain size increases upwards, and starved oscillation-ripple lamination is common between 1.30 and $1.57 \mathrm{~m}$, but the sediment is nonburrowed. Logically, wave agitation should aerate the water column. The absence of infauna points to two possibilities: (1) the presence of dysaerobic conditions throughout the water column, or (2) sedimentation in a freshwater system. In this example, dysaerobic water is the preferred interpretation because the overlaying stratum, which is interpreted to be a part of the same depositional system, is heavily bioturbated and contains a marginal marine ichnofauna (see below). Alternatively, the unburrowed zones might reflect taphonomic bias due to lack of lithological contrast (cf. MacEachern et al. 1999), but laminae in the mud are continuous and show no signs of biogenic disruption.

At $1.57 \mathrm{~m}$, a sharp-based, bioturbated sand is present. Hummocky cross stratification at the base was generated by storm waves. Above $1.65 \mathrm{~m}$, the stratification has been eradicated by biogenic reworking. In this case, Teichichnus, Thalassinoides, Helminthopsis, Planolites, and Palaeophycus form a stressed, proximal Cruziana Ichnofacies, consistent with lower baymargin ichnofossil assemblages (Pemberton et al. 1992). Because of the larger size of the trace fossils and intense reworking of the sediment, dysaerobic conditions are discounted as a notable stress at this level. Rather, the low diversity of trace fossils, their (normally) marginal marine affinities, and the trophic generalist behaviors, as well as the high degree of bioturbation, are all consistent with bioturbation in brackish-water environments (Pemberton et al. 1982; Beynon and Pemberton 1992; MacEachern and Pemberton 1994; Ranger and Pemberton 1997; Gingras et al. 1999). As with SJC, this sharp-based sand is interpreted to be the remnant of a prograding, erosionally based bay margin.

The discontinuous nodular horizon $(2.15 \mathrm{~m})$ may reflect slow sedimentation rates, as discussed earlier. Massive muds, crosscut by roots, comprise the rest of the section. These are interpreted to be lagoonal, because of the extremely stressed ichnofacies (small Planolites and Thalassinoides), and the position of the mud above bay-margin sand and below rooted lignite. For reasons outlined below, the lignite at $(3.08 \mathrm{~m})$ is thought to represent the transgressive base of Parasequence TmB.

Interpretation of Parasequence B (TmB).-A Glossifungites-demarcated discontinuity is present at the base of the Tamshiyacu succession, indicating the presence of a TSE. The shell bed above the surface shows signs of reworking, and is interpreted to represent a winnowed, low-energy, transgressive lag.

Nonburrowed organic clay $(3.40 \mathrm{~m})$ was deposited during maximum flooding. As with Parasequence TmA, starved oscillation ripples precede the appearance of notable bioturbation $(3.50 \mathrm{~m})$. Rare current ripples were developed during or immediately following higher-energy events. Overall, the trace fossils, which include Planolites, Palaeophycus, Skolithos, Arenicolites, Gyrolithes, and Cylindrichnus, are diminutive, exhibit a low diversity, and are sporadically distributed. The low diversity of trace fossils, the inclusion of trophic-generalist behavior, the extremely small size of some ichnofossils, and their sporadic distribution suggest that salinitystressed conditions helped shape the benthic community. Zones that are impoverished either reflect dysaerobic conditions or are the result of taphonomic bias due to lack of lithological contrast (cf. MacEachern et al. 1999).

From 4.10 to $5.20 \mathrm{~m}$, increased sand and the preponderance of oscillation ripples reflect continued shoaling. The general absence of trace fossils throughout this zone is attributed to one or more of the following processes: rapid sediment aggradation; common hydraulic reworking of the sediment; extreme water chemistries, such as fluctuating salinity, fresh water incursion, or anoxia, and/or extreme turbidity. Of these, the overall sedimentary character (including the presence of clean laminae) of the deposit indicates that unsuitable water chemistries for benthic colonization best explain the paucity of bioturbation.

Above $5.40 \mathrm{~m}$, low-angle cross lamination and oscillation ripples are attributed to storm-event beds. These pass upward into a bioturbated, coarsening-upwards sand bed (5.72 to $6.20 \mathrm{~m}$ ) that represents further progradation of the shoreline system. Ichnogenera present include Thalassinoides, Ophiomorpha, Diplocraterion, and Arenicolites. The low diversity of ichnogenera, overall high degrees of bioturbation, small to moderate sizes of trace fossils, and the use of trophic generalist behaviors are most like brackish-water, marginal marine ichnocoenoses (outlined above). Because of the erosional truncation of Parasequence TmA, it is difficult to assign the bioturbated media (5.72 to $6.20 \mathrm{~m}$ ) to a discrete depositional environment. Its position in the parasequence and the trace-fossil assemblage suggest that the bed is: (1) depositionally higher in a low-energy bay-margin system, 
or (2) represents backshore sediment accumulation in a brackish-water lagoon.

A deformed shell lag underlain by a Glossifungites-demarcated discontinuity is present at the top of the parasequence, which is again interpreted to represent a TSE.

\section{DISCUSSION}

\section{Ichnology}

Three recurring ichnofossil assemblages show that marine and brackish waters, not freshwater, were present during parasequence development. These are: (1) a dysaerobic, brackish-water to marine, Chondrites-reburrowed Planolites ichnofabric resident only in very fine massive muds (F1B) (Fig. 4A); (2) a brackish-water to marine, Scolicia, Thalassinoides, Ophiomorpha ichnofabric (F2B) (Figs. 3D, E, and F); and (3) a brackishwater, Thalassinoides-generated ichnofabric that is interpreted to have descended into consolidated substrates, and thus represents the Glossifungites Ichnofacies (F3C) (Figs. 3C, 4D). Although absolute salinity is difficult to assess from trace-fossil data, modern studies suggest that Scolicia, which is produced by irregular urchins in modern deposits (Seilacher 1986; Fu and Werner 2000), may serve as an upper mesohaline to marine indicator. This is due to the low tolerance of urchins to brackish- and fresh-water conditions (Irlandi et al. 1997; Basuyaux et al. 1998; Metaxas 1998). Likewise, Chondrites is commonly taken to indicate brackish to marine waters, and, although the Chondrites-tracemaker's potential tolerance to brackishwater has not yet been not established, Chondrites has been reported in marine deposits from hundreds of studies. In contrast, reports of Chondrites in continental deposits are rare. Two notable studies warrant comment: (1) Archer and Maples (1984) reported that Chondrites is present in nonmarine Pennsylvanian strata in southwestern Indiana. These are marginal marine and continental strata deposited in a deltaic setting. We respectfully contend that complex stratigraphic relationships may provide alternative solutions to that study. (2) Hu (1994) suggested that Chondrites, Palaeodictyon, Protopalaeodictyon, and Granularia constituted the ichnofabric present in lacustrine turbidites. This represents an anomalous lacustrine trace-fossil assemblage. In fact, the ichnology of ancient lacustrine systems is generally limited to surface and interface tracks and burrows; Scoyenia, Planolites, Helminthopsis, Beaconites, Taenidium, Rusophycus, Umfolozia, as well as irregularly branching burrows are by far the dominant ichnofossils in lacustrine settings (Buatois et al. 1996; Buatois and Mángano 1998).

Notably, abundant ichnological and neoichnological evidence show that tubular, smooth-walled, regularly branching Thalassinoides are a marginalmarine to marine phenomena (Shinn 1968; Rice and Chapman 1971; Frey and Howard 1975; Frey et al. 1978; Dworshak 1983; Griffis and Chavez 1988; Gingras et al. 2000). Modern studies show that in firmgrounds, these trace fossils are made by thalassinid shrimp (Gingras et al. 2000; Gingras et al. 2001), which indicates that sedimentation occurred in mesohaline to marine waters.

\section{Parasequence Architecture}

The parasequences are thin, ranging between 2.5 and $4.0 \mathrm{~m}$ thick $(\mathrm{TmA}$ and SJC, respectively). The Santa Julia A and B, and TmB are incomplete, inasmuch as they are truncated by TSE (Figs. 2, 5). In the cases of SJC and $\mathrm{TmA}$, middle parts of the parasequence are eroded, as inferred from the presence of a Glossifungites-demarcated discontinuity possibly associated with a RSE. Also, SJC and TmA have TSE at their tops (Figs. 2, 5). Thin, erosionally amalgamated parasequences reflect reduced amounts of accommodation space available for sediment accumulation.

Relatively repetitive parasequence thickness resulted from rapid, meterscale, pulsed tectonic subsidence, associated with orogenic activity in the Andean mountains. This activity is believed to have induced several fourthand fifth-order cycles in other South American basins during early and late
Miocene times (Bao et al. 1999; Saez et al. 1999). Following subsidence, embayment waters transgressed the low-gradient continental plain, truncating preexisting shoreline deposits (Fig. 5A). The shallow, broad sediment-accommodation zone was rapidly filled with prograding marginalmarine, bay-margin deposits. Locally, the bay margin eroded into the distal bay sediments as the shoreline prograded (RSE; Fig. 5B).

The bay-margin deposits that are described in Parasequences SJC and $\mathrm{TmA}$ are thin. In both parasequences, the sharp-based bay-margin strata grade upwards into lagoonal or backshore deposits, over thicknesses of 1.0 to $1.5 \mathrm{~m}$. The thinness of the Pebas bay-margin sands is attributed to a very shallow wave base that, in effect, compressed subtidal, foreshore, and backshore deposits into a thin sedimentary package. The shallow wave base was potentially promoted by the very low-gradient depositional dip that dissipated wave energy over an exceptionally broad zone.

Restricted (dysaerobic) distal bay deposits provide a striking contrast to the burrowed, marginal marine sands observed in association with transgressive and regressive bay-margin deposits (Fig. 5). The basinal waters were probably layered and dysaerobic. This may have been the result of salinity layering in a quiescent depositional system. A result of layered bay waters is that the ichnofacies are strongly linked to the water energy. Parasequences developed under these conditions should be anticipated and will likely consist of (Fig. 5): (1) a TSE, demarcated by the Glossifungites Ichnofacies (F3C) infilled with sediment that is derived from the immediately overlaying bioturbated sand (F2B); (2) an overlying, sporadically bioturbated mud that exhibits a dysaerobic, marine suite of trace fossils; (3) a gradational or erosional transition into bioturbated bay margin sands; and (4) a capping regressive lignite or a TSE with a transgressive lignite.

\section{Reconciliation with Previous Work}

The findings of this study are significant in that they demonstrate a marine influence in the Middle Miocene (14-10 Ma) in the Amazonas-Solimöes Basin. The strongest data against persistent marine incursion come from isotopic data, particularly $\mathrm{Sr}$ ratios, and ${ }^{18} \mathrm{O}$ and ${ }^{13} \mathrm{C}$ enrichment (Vonhof et al. 1998). These databases were derived from the abundant mollusk fossils present in Pebas strata. Notably, no cosmopolitan (marginal marine) shelly fauna is observed. Oysters, arcshells, and littoridinids are conspicuously absent. Also, the preserved mollusk assemblage is most consistent with those observed in limnitic systems (Vonhof et al. 1998).

Strontium isotope data (Vonhof et al. 1998) indicate that the upper Pebas had a primarily fresh-water origin (up to 5\%o salinity). Although the methodology and interpretation of the Sr data are correct, they are dependent upon two assumptions. The first is the degree of accuracy to which $\mathrm{Sr}$ isotopic proportions are known for the middle Miocene (approximately 14$11 \mathrm{Ma}$ ); the second is that $\mathrm{Sr}$ concentrations in modern Andean- and shieldderived freshwater provide good proxies for Miocene fluvial sources. Shifts in these values would markedly change the mixing curves presented in Vonhof et al. (1998) and change the predicted salinities. In the case of ${ }^{13} \mathrm{C}$ and ${ }^{18} \mathrm{O}$, their depletion can be explained by mixing meteoric with marine water. As with strontium values, baselines for Miocene ${ }^{18} \mathrm{O}$ enrichment are uncertain and probably varied appreciably. Notably, much of the mollusk data (at least 12 of 17 sample points) presented in Vonhof et al. (1998) are derived from samples located immediately above parasequence boundaries, or very near lignitic accumulations. Because the database is biased towards the tops and bases of parasequences, we suggest that this isotopic database reflects the most extreme nonmarine conditions in the system and that the data support our interpretations.

Our observations bolster those of Räsänen et al. (1995) who reported the presence of tidalites near the Madre de Díos-Beni basin. Notably, Von Ihering (1927) proposed a similar paleogeography based on foraminifera data. The potential presence of an extensive Miocene embayment seaway merits further research because of its implications regarding the understanding of the paleogeographical, paleoenvironmental, and paleoecological de- 
velopment and origin of Amazonian biota (Räsänen et al. 1995; Webb 1995).

\section{CONCLUSIONS}

A detailed analysis of the ichnology and sedimentology of the Pebas Formation at Santa Julia and Tamshiyacu leads to several conclusions.

1. Three recurrent ichnofossil assemblages show that marine and brackish waters were present during the time of sediment deposition: (1) a dysaerobic, brackish-water to marine Chondrites-reburrowed, Planolites ichnofabric observed in massive muds; (2) a brackish-water to marine, Scolicia, Thalassinoides, Ophiomorpha ichnofabric that is manifested as intensely bioturbated silty sands, and; (3) a brackishwater, Thalassinoides-generated, Glossifungites Ichnofacies.

2. Sediment accumulation occurred in bay-margin environments that prograded into a shallow, quiescent (very shallow wave base) bay.

3. A stratified water column is evidenced by the ichnofauna; the trace assemblage is robust only where a sedimentary record of hydraulic energy is preserved.

4. Low accommodation space, repetitive and rapid adjustments of relative sealevel, shallow wave base, and a stratified water column all combined to generate an unusual, but predictable parasequence architecture.

5. Previously published isotopic data is consistent with sediment accumulation in brackish to marine water if the stratigraphic location of the isotopic sample locations are considered and a stratified water column is recognized.

6. Marine incursion into Amazonia occurred during the Middle Miocene. Future research should focus on the temporal and paleogeographical extent of that event.

\section{ACKNOWLEDGMENTS}

Gratitude is extended to the Academy of Finland (project numbers: 42760, 45923) for their financial support. Frank Wesselingh, Hubert Vonhof, and James MacEachern provided invaluable initial comments. Also, we would like to thank Elba Maria Ponce Arias, Ruben Perez, Luisa Rebata, Jussi Hovikoski, Pekka Räsänen, and Petri Siiro for capable field assistance. The manuscript enjoyed significant improvement by Andrew Rindsberg, Charles Savrda, and James MacEachern, who reviewed this research paper. Dr. Mary Kraus provided very helpful editorial comments. Vivienne Robertson assisted with manuscript preparation.

\section{REFERENCES}

Archer, A.W., AND Maples, C.G., 1984, Trace-fossil distribution across a marine-to-nonmarine gradient in the Pennsylvanian of southwestern Indiana, in Miller, M.F., Ekdale, A.A., and Picard, M.D., eds., Trace Fossils and Paleoenvironments; Marine Carbonate, Marginal Marine Terrigenous and Continental Terrigenous Settings, Journal of Paleontology. v. 58, p. 448-466.

AtKInson, R.J.A., 1974, Behavioral ecology of the mud-burrowing crab, Goneplex rhomboides: Marine Biology, v. 25, p. 239-252.

BaO, R., SAeX, A., Servant, V.S., and Cabrera, L., 1999, Lake-level and salinity reconstruction from diatom analyses in Quillagua Formation (late Neogene, central Andean forearc, northern Chile): Palaeogeography, Palaeoclimatology, Palaeoecology, v. 153, p. 309-335.

Basuyaux, O., Mathieu, M., And Day, C., 1998, Effects of salinity on diet and growth of the sea urchin Paracentrotus lividus and the abalone Haliotis tuberculata: Société Zoologique de France, Bulletin, v. 123, p. 141-150.

Beynon, B.M., And Pemberton, S.G., 1992, Ichnological signature of a brackish water deposit: an example from the Lower Cretaceous Grand Rapids Formation, Cold Lake oil sands area, Alberta, in Pemberton, S.G., ed., Applications of Ichnology to Petroleum Exploration: SEPM, Core Workshop Notes 17, p. 199-221.

Bromley, R.G., 1996, Trace Fossils, 2nd Edition: Suffolk, U.K., Chapman \& Hall, 361 p.

Bromley, R.G., and Ekdale, A.A., 1984, Chondrites: a trace fossil indicator of anoxia in sediments: Science, v. 224, p. 872-874.

Buatois, L.A., And Mángano, M.G., 1998, Trace fossil analysis of lacustrine facies and basins: Palaeogeography, Palaeoclimatology, Palaeoecology, v. 140, p. 367-382.

Buatois, L.A., Mángano, M.G., Wu, X., and Zhang, G., 1996, Trace fossils from Jurassic lacustrine turbidites of the Anyao Formation (central China) and their environmental and evolutionary significance: Ichnos, v. 4, p. 287-303.

Cornwell, J.C., Conley, D.J., Owens, M., and Stevenson, J.C., 1996, A sediment chronology of the eutrophication of Chesapeake Bay: Estuaries v. 19, p. 488-499.
Dworschak, P.C., 1983, The biology of Upogebia pusilla (Petagna) (Decopoda, Thalassinidae): Marine Ecology, v. 4, p. 19-43.

Ekdale, A.A., Bromley, R.G., and Pemberton, S.G., 1984, Ichnology; Trace Fossils in Sedimentology and Stratigraphy: SEPM, Short Course 15, $317 \mathrm{p}$.

FARRow, G.E., 1971, Back-reef and lagoonal environments of Aldabra Atoll distinguished by their crustacean burrows: Zoological Society of London, Symposia, v. 28, p. 455-500.

Frey, R.W., AND HowARD, J.D., 1975, Endobenthic adaptations of juvenile thalassinid shrimp: Geological Society of Denmark, Bulletin, v. 24, p. 283-297.

Frey, R.W., Howard, J.D., And PrYoR, W.A., 1978, Ophiomorpha; Its morphologic, taxonomic, and environmental significance: Palaeogeography, Paleoclimatology, Palaeoecology, v. 23, p. 199-229.

FREY, R.W., AND SEILACHER, A., 1980, Uniformity in marine invertebrate ichnology: Lethaia, v. 13 , p. $183-207$.

Fu, S., AND Werner, F., 2000, Distribution, ecology and taphonomy of the organism trace Scolicia, in northeast Atlantic deep-sea sediments: Palaeogeography, Paleoclimatology, Palaeoecology, v. 156, p. 289-300.

Gaffney, E.S., Campbell, K.E., and Wood, R.C., 1998, Pelomedusoid side-necked turtles from late Miocene sediments in southwestern Amazonia: American Museum Novitates, no. 3245 p. $1-11$.

Gingras, M.K., MacEachern, J.A., and Pemberton, S.G., 1998, A comparative analysis of the ichnology of wave- and river-dominated allomembers of the Upper Cretaceous Dunvegan Formation. Bulletin of Canadian Petroleum Geology, v. 46, p. 51-73.

Gingras, M.K., Hubbard, S.M., Pemberton, S.G., and Saunders, T.D.A., 2000, The significance of Pleistocene Psilonichnus at Willapa Bay, Washington: Palaios, v. 15, p. 142-151.

Gingras, M.K., Pemberton, S.G., Saunders, T.D.A., and Clifton, H.E., 1999, The ichnology of modern and Pleistocene brackish-water deposits at Willapa Bay, Washington: variability in estuarine settings: Palaios, v. 14, p. 352-374.

Gingras, M.K., Pemberton, S.G., and Saunders, T.D.A., 2001, Bathymetry, sediment texture, and substrate cohesiveness; their impact on modern Glossifungites trace assemblages at Willapa Bay, Washington: Palaeogeography, Palaeoclimatology, Palaeoecology, v. 169, p. $1-21$.

GingRas, M.K., RÄSÄNEN, M., AND M. RANZI, A., 2002, The significance of bioturbated inclined heterolithic stratification in the southern part of the Miocene Solimoes Formation, Rio Acre, Amazonia Brazil: Palaios, v. 17, n. 6, in press.

Griffis, R.B., AND Chavez, F.L., 1988, Effects of sediment type on burrows of Callianassa californiensis Dana and C. gigas Dana: Experimental Marine Biology and Ecology, v. 117, p. 239-253.

Hasiotis, S.T., and Honey, J.G., 2000, Paleohydrologic and stratigraphic significance of crayfish burrows in continental deposits: examples from several Paleocene Laramide basins in the Rocky Mountains: Journal of Sedimentary Research, v. 70, p. 127-139.

Hollander, D.J., McKenzie, J.A., AND Lo-Ten, H.H., 1992, A 200 year sedimentary record of progressive eutrophication in Lake Greifen (Switzerland); implications for the origin of organic-carbon-rich sediments: Geology (Boulder), v. 20, p. 825-828.

Hooghiemstra, H., and Van Der Hammen, T., 1998, Neogene and Quaternary development of the neotropical rain forest; the forest refugia hypothesis, and a literature overview: EarthScience Reviews, v. 44, p. 3-4.

Hoorn, C., 1993, Marine incursions and the influence of Andean tectonics on the Miocene depositional history of northwest Amazonia: results of a palynostratigraphic study: Palaeogeography, Paleoclimatology, Palaeoecology, v. 105, p. 267-309.

Hu, B., 1994, Late Triassic-Middle Jurassic continental strata in Jiyuan, Henan, China: Dicengxue Zazhi, v. 15, p. 48-52.

HumPHREYs, B., AND BALSON, P.S., 1988, Psilonichnus (Fürsich) in Late Pliocene subtidal marine sands of Eastern England: Journal of Paleontology, v. 62, p. 168-17.

Irlandi, E., Macia, S., AND SERAF, J., 1997, Salinity reduction from freshwater canal discharge: Effects on mortality and feeding of an urchin (Lytechinus variegatus) and a gastropod (Lithopoma tecum): Bulletin of Marine Science, v. 61, p. 869-879.

Loope, D.B., And Dingus, L., 1999, Mud-filled Ophiomorpha from Upper Cretaceous continental redbeds of southern Mongolia; an ichnologic clue to the origin of detrital, graincoating clays: Palaios, v. 14, p. 451-458.

Lundberg, J.G., Marshall, L.G., Guerrero, J., Horton, B., Malabarba, M.C.S.L., and WesSELINGH, F., 1998, in Malabarba, E.L., et al., eds., Phylogeny and Classification of Neotropical Fishes, (Edipucrs, Porto Alegre), p. 13-48.

MacEachern, J.A., And Pemberton, S.G., 1992, Ichnologic aspects of Cretaceous bay margin successions and bay margin variability in the Western Interior Seaway of North America in Pemberton, S.G., ed., Applications of Ichnology to Petroleum Exploration: SEPM, Core Workshop, Notes 17, p. 57-84.

MacEachern, J.A., and Pemberton, S.G., 1994, Ichnological aspects of incised-valley fill systems from the Viking Formation of the Western Canada sedimentary basin, Alberta, Canada, in Dalrymple, R.W., Boyd, R., and Zaitlin, B.A., eds., Incised-Valley Systems; Origin and Sedimentary Sequences: SEPM, Special Publication 51, p. 129-157.

MacEachern, J.A., Stelck, C.R., and Pemberton, S.G., 1999, Marine and marginal marine mudstone deposition: paleoenvironmental interpretations based on the integration of ichnology, palynology and foraminiferal paleoecology, in Bergman, K.M., and Snedden, J.W., eds., Isolated Shallow Marine Sand Bodies; Sequence Stratigraphic Analysis and Sedimentologic Interpretation: SEPM, Special Publication 64, p. 205-225.

MetaXas, A., 1998, The effect of salinity on larval survival and development in the sea urchin Echinometra lucunter: Invertebrate Reproduction and Development, v. 34, p. 323-330.

Monsch, K.A., 1998, Miocene fish faunas from the northwestern Amazonia basin (Colombia, Peru, Brazil) with evidence of marine incursions: Palaeogeography, Paleoclimatology, Palaeoecology, v. 143 , p. 31-50.

NoRes, M., 1999, An alternative hypothesis for the origin of Amazonian bird diversity: Journal of Biogeography, v. 26, p. 475-485. 
Nuttall, C.P., 1990, A review of the Tertiary non-marine molluscan faunas of the Pebasian and other inland basins of north-western South America: British Museum of Natural History, Bulletin (Geology), v. 45, p. 165-372.

Pemberton, S.G., Flach, P.D., and Mossop, G.D., 1982, Trace fossils from the Athabasca oilsands, Alberta, Canada: Science, v. 217, p. 825-827.

Pemberton, S.G., and Frey, R.W., 1985, The Glossifungites Ichnofacies: Modern examples from the Georgia coast, U.S.A., in Curran, H.A., ed., Biogenic Structures: Their Use in Interpreting Depositional Environments: SEPM, Special Publications 35, p. 237-259.

Pemberton, S.G., and MacEAchern, J.A., 1995, The sequence stratigraphic significance of trace fossils: Examples from the Cretaceous foreland basin of Alberta, Canada, in Van Wagoner, J.C., and Bertram, G.T., eds., Sequence Stratigraphy of Foreland Basin Deposits: American Association of Petroleum Geologists, Memoir 64, p. 429-475.

Pemberton, S.G., and MacEachern, J.A., 1997, The ichnological signature of storm deposits: the use of trace fossils in event stratigraphy, in Brett, C.E., and Baird, G.C., eds. Paleontological Events: New York, Columbia University Press, p. 73-109.

Pemberton, S.G., MacEachern, J.A., and Frey, R.W., 1992, Trace fossil facies models: environmental and allostratigraphic significance, in Walker, R.G., and James, N.P., eds., Facies Models: Response to Sea Level Change: Geological Association of Canada, p. 47-72.

Posamentier, H.W., and Allen, G.P., 1999, Siliciclastic Sequence Stratigraphy-Concepts and Applications: SEPM, Concepts in Sedimentology and Paleontology, v. 7, 210 p.

Rancy, A., 1991, Pleistocene mammals and paleoecology of the western Amazon [unpublished Ph.D. thesis]: University of Florida, $151 \mathrm{p}$.

Ranger, M.J., and Pemberton, S.G., 1997, Elements of a stratigraphic framework for the McMurray Formation in South Athabasca area, Alberta, in Pemberton, S.G., and James, D.P., eds., Petroleum Geology of the Cretaceous Mannville Group, Western Canada: Canadian Society of Petroleum Geologists, Memoir 18, p. 263-291.

Räsänen, M.E., Linna, A.M., Irion, G., Rebata Hernani, L.A., Vargas Huaman, R., and WesSELINGH, F.P., 1998, Geología y geoformas de la zona de Iquitos, in Kalliola, R., and Flores Paitán, S., eds., Geoecología y Desarrollo Amazónico: Estudio Integrado en la Zona de Iquitos, Perú: Annales Universitatis Turkuensis, Ser. A II, p. 59-137.

Räsänen, M.E., Linna, A.M., Santos, J.C.R., And Negri, F.R., 1995, Late Miocene tidal deposits in the Amazonian foreland basin: Science, v. 269, p. 386-390.

Rice, A.L., AND ChaPMAN, C.J., 1971, Observations on the burrows and burrowing behavior of two mud-dwelling decapod crustaceans, Nephrops norvegicus and Goneplax rhomboides: Marine Biology, v. 10, p. 330-342.
Roy, P.S., Cowell, P.J., Ferland, M.A., and Thom, B.G., 1994, Wave-dominated coasts, in Carter, R.W.G., Woodrofe, C.D., eds., Coastal Evolution; Late Quaternary Shoreline Morphodynamics: Cambridge, U.K., Cambridge University Press, p. 121-186.

Saez, A., Cabrera, L., Jensen, A., And Chong, G., 1999, Late Neogene lacustrine record and palaeogeography in the Quillagua-Llamara Basin, central Andean fore-arc (northern Chile), in Cabrera, L., and Saez, A., eds., Ancient and Recent Lacustrine Systems in Convergent Margins; Proceedings of an International Symposium of IGCP 324 "Global Palaeoenvironmental Archives in Lacustrine Systems; GLOPALS': Palaeogeography, Palaeoclimatology, Palaeoecology, v. 151, p. 5-37.

Sageman, B.B., Wignall, P.B., and Kauffman, E.G., 1991, Biofacies models for oxygen-deficient facies in epicontinental seas: tool for paleoenvironmental analysis, in Einsele, G., Ricken, W., and Seilacher, A., eds., Cycles and Events in Stratigraphy: Berlin, SpringerVerlag, p. 542-564.

SavRda, C.E., AND BotTJER, D.J., 1989, Trace fossil models for reconstructing oxygenation histories of ancient marine bottom waters: application to Upper Cretaceous Niobrara Formation, Colorado: Palaeogeography, Paleoclimatology, Palaeoecology, v. 74, p. 49-57.

Savrda, C.E., Krawinkel, H., McCarthy, F.M.G., and McHugh, C.M.G., 2001, Ichnofabrics of a Pleistocene slope succession, New Jersey margin: relations to climate and sea-level dynamics: Palaeogeography, Palaeoclimatology, Palaeoecology, v. 171, p. 41-61.

SeILACHER, A., 1986, Paleontological studies on turbidite sedimentation and erosion: Journal of Geology, v. 70, p. 227-234.

SHinN, E.A., 1968, Burrowing in recent lime sediments of Florida and the Bahamas: Journal of Paleontology, v. 42, p. 879-894.

Smith, A.B., AND CRIMES, T.P., 1983, Trace fossils formed by heart urchins: a study of Scolicio and related traces: Lethaia, v. 16, p. 79-92.

Van Der Hammen, T., and Hooghiemstra, H., 2000, Neogene and Quaternary history of vegetation, climate, and plant diversity in Amazonia: Quaternary Science Review, v. 19, p. $725-742$.

Von IHeRING, H., 1927, Die Geschichte des Atlantischen Ozeans: Jena, Germany, Fischer.

Vonhof, H.B., Wesselingh, F.P., and Ganssen, G.M., 1998, Reconstruction of the Miocene western Amazonian aquatic system using molluscan isotopic signatures: Palaeogeography, Paleoclimatology, Palaeoecology, v. 141, p. 85-93.

WebB, S.D., 1995, Biological implications of the middle Amazon Seaway: Science, v. 269, p. 361-362.

Received 18 December 2000; accepted 20 May 2002 